\title{
On the Merits of Decentralization in Young Democracies
}

\author{
Wolf Linder*
}

Three features of decentralization proposed by institutional development theory are analyzed for Mozambique's Autarquias, politically autonomous municipalities since 1997. The three issues analyzed in this article are: Consolidation of the fiscal state, democracy, and the development of service quality in the local administration. Under decentralization, each of the three features is shown empirically to allow progress toward political development. Using QCA-analysis, the politics contributing to institutional consolidation are identified. While the different socio-economic contexts of the Autarquias and power sharing play an important role, the effects of direct participation are more ambiguous. Decentralization can contribute to a "state closer to the people" and may correct the deficiencies of "top down" politics characterizing many African States. However, decentralization cannot overcome deep socio-political divides such as those existing in Mozambique within such a short time. Finally, positive development towards consolidation of democracy, of the local state and its service quality depend on different patterns of politics, more complex than general theories propose.

\section{Introduction}

In the discussion of countries in transition, theories of federalization and decentralization are attracting increasing interest from both academics and practitioners. Devolution of power, de-concentration, fiscal decentralization or even federalization appear to be helpful devices, bringing the state closer to the people and allowing ownership among citizens to develop. These devices allow people to express their needs more effectively and enable authorities to develop fiscal autonomy and deliver public services more efficiently. When power is shared vertically, the integration of segmented or even divided societies has a better chance to succeed. In smaller units, the chance of efficient governance and of sanctioning corruption seems to be higher (Baechler 1997, Kaelin 1999, Lijphart 1999, Litvack et al. 1998, Manor 1999, Sisk 2001). Last but not least: Decentralization is

*Institute of Political Science, University of Bern; wolf.linder@ipw.unibe.ch

Publius: The Journal of Federalism volume 40 number 1, pp.1-30

doi:10.1093/publius/pjp027

Advance Access publication 22 October 2009

(C) The Author 2009. Published by Oxford University Press on behalf of CSFAssociates: Publius, Inc.

All rights reserved. For permissions, please email: journals.permissions@oxfordjournals.org. 
claimed to be one of the few credible answers to the failures of the central state in Sub-Saharan Africa (Oluwu and Wunsch 2004).

In this article, I provide a case study of the decentralization experience of Mozambique's municipalities, and will determine whether or not this experience provides empirical evidence of these theoretical claims: Does decentralized governance improve the quality of democracy, of public services, and of the capacities of the local State to collect taxes for public goods? I begin with a brief account of the circumstances leading to the enactment of the Autarquias through the central government in 1997, and an overview of the basic institutional features of the municipalities. The next section presents the concept of the study. It is focused on three topics of institutional development mentioned above: Consolidation of the local state and of democracy, and on the development of service quality for the people in the Autarquias. A causal model conceives these outcomes of decentralization as dependent on local politics and their socioeconomic context. The next two sections present the results of an empirical investigation on a sample of twelve of the thirty-three Autarquias. These descriptive parts are followed by a comparative analysis, testing hypotheses on the effects of local politics and of the socio-economic context with regard to consolidation. A QCA-Analysis tries to explain why some of the Autarquias perform better than others. The article concludes with an interpretation of the findings and a more general outlook.

\section{Mozambique's Autarquias and Their Policy}

Mozambique was granted independence in 1975 from the Portuguese and suffered civil war until 1992, when a peace agreement was signed and democratic reforms installed. The main protagonists of this conflict were Frelimo (Frente de Liberatacao de Mocambique), a Marxist-Leninist liberation movement on one side and Renamo (Resistencia Nacional Mocambicana-Uniao), a guerilla organization, supported by the regimes of South Africa and Rhodesia on the other. After the peace agreement, the military organizations both disarmed, becoming the two major competitive political parties in the first pluralist elections of 1994. Frelimo is based primarily on urban middle classes in the south, while Renamo's strongholds are in the centre and north of this country of nineteen million. Frelimo was always the ruling force in a one-party regime before constitutional reforms of 1990, and has remained dominant in an imperfect democracy since. Frelimo is said to have a record of election fraud. Moreover, it is reported to lead by the exclusion of Renamo members from most political, administrative, economic and social positions. Renamo politicians have been jailed and their party activities restricted (Braathen 2003). Despite a remarkable peace-making process, Mozambique's society is still deeply divided. In some ways, the Frelimo regime resembles a 
one-party-regime. Yet, maintaining the rules of formal democracy may be important to guarantee political stability and to fulfill conditions imposed by foreign donors who support the budget. The international donor community finances fifty percent of central government operations.

The Frelimo regime steers a centralist course. In terms of economics, it has abandoned its Marxist concepts and created open markets, which have achieved steady income growth from low initial income levels. One of the few exceptions of Frelimo's centralist policy was the creation of the thirty-three "Autarquias" between 1994 and 1997. Twenty-three cities within the country and ten district towns were given considerable political autonomy, while another 106 district towns ("vilas") of the country exist on a purely administrative de-concentration of provinces and districts.

The Autarquias ${ }^{1}$ are responsible for a number of local programs (planning and development of local infrastructure, schools, health and social services, regulation of local markets), and have the right to levy personal, market, real estate and other taxes and to receive fund transfers from central government. Their elected authorities include the Mayor, who nominates members of a five to seven member Council, and the Municipal Assembly, a legislative body of between fifteen and forty members, elected by proportional rule. The Autarquias are sub-divided into so called "bairros", in which a "Community Leader" maintains the link between the people of each subdivision and the authorities. The legitimacy of Community Leaders has increased because they are part of the local political institutions. Formerly, a secretary nominated by the ruling party fulfilled these roles.

The process of decentralization is always political, accompanied by conflict as new actors gain and old actors lose power (Linder 2002). In the case of Mozambique, the decision to make some, but not all of the district towns autonomous appears to be a compromise between those in favor of decentralization of the entire political system and those opposed to any devolution of powers away from the central authorities. At the beginning, State ministries, province and district authorities defended their prerogative to maintain power, which brought the new institutions of Autarquias in conflict with the existing power structure of the higher authorities. The mentality of a centralist bureaucracy created difficulties for the Autarquias to exercise their new roles. Competencies were unclear. Government transfers to the municipalities failed to arrive.

While relations between state authorities and municipalities are still far from perfect, the rules of the game, meanwhile, have become clearer. The autonomy of municipalities is more or less defined and respected at upper levels, and many tensions between the local and district authorities were alleviated by intervention of the central government. Even so, the ruling Frelimo elite seem to have ambiguous feelings about the decentralization they initiated. Plans to extend the number 
of Autarquias at the beginning of the new millennium were postponed (Braathen 2003).

Elections for the Autarquias were held in 1998 and 2003. Renamo, the opposition party, boycotted the first elections so that all Autarquias remained in the hands of Frelimo. In 2003, Renamo participated in the elections and won power in five of the thirty-three local governments. The few Autarquias with Renamo governments are the only places where Frelimo has lost some of its control over the political, social and economic networks of Mozambique's society.

In building local institutions, responsible actors had to begin from scratch. Politicians had no prior experience, and professional staff-with the exception of administrative personnel taken over from district authorities-did not exist. Moreover, no one knew anything about municipalities. Since then, many things have changed. Training programs for administrative and political functions, financially supported by the central government and foreign donors, have been organized in all Autarquias. The institutions are installed, local administrations function; political authorities are in office and compete in elections.

\section{Assessing the Merits of Decentralization}

After less than ten years in existence, Mozambique's Autarquias are still in the making, thus in a process of consolidation. The original policy plans of the Mozambique authorities for decentralization contain the objectives of "creating the state and of citizenship from below" (Sitoe and Hunguana 2007:14). Each of the three particular topics of this study-outcomes on the development of the fiscal state, of service quality and of democracy_can therefore be seen as an important element of institutional consolidation of the Autarquias. Their theoretical connotations - as developed by Merkel (2004), Schneider and Schmitter (2004), and Moore (2001) — and their particular significance for the Mozambique case are explained in the following.

Much of the governance literature suggests that the goals of democratization, public service quality and fiscal consolidation are compatible with each other or even create synergies. However, it should not be overlooked that in political development there may be conflict between these three elements. As Moore (2001:390) points out, foreign aid can improve public services for the people but make authorities less responsive to the electorate. This can hinder the political development of democracy, or lessen the incentives for authorities to improve fiscal revenues to a sustainable level. Another trade-off mentioned by Moore (2001) is the dilemma between state and democracy development. On one hand, the "statist" perspective insists upon the importance of a "strong" state, capable of delivering public goods by means of its own fiscal resources, despite the fact that strong authorities can follow the negative path of an authoritarian regime. On the 
other hand, the opposing "liberal" position insists on constitutional guarantees, democracy and liberties that protect citizens against the state. However, a "weak" state may be incapable of developing credible institutions that go beyond clientelism (Davidson 1992). For all these reasons, we analyze the three dimensions of consolidation separately.

This study postulates that the outcomes of consolidation are dependent on the political process, visualized as a causal model in Figure 1. Causality is postulated because politics not only illustrate the way how institutions are used but also influence the way institutions develop over time. While the institutional design for each Autarquia is identical, how political actors use the institution can vary from place to place. This variance can be particularly high in developing institutions and in sub-Saharan states where formal institutions are often overruled by the "informal" process of politics (Hyden 2006). For some of the informal processes, such as clientelism or discrimination, reliable information is barely available for the outside observer. Therefore, in developing the final version of this concept, I had to concentrate on those variables of local politics for which it was possible to collect sufficient and reliable data. The first variable indicates the degree to which the legal rule of separation between executive and legislative is respected in political practice. In the second variable, power sharing, the focus is on relations between the two political parties, Frelimo and Renamo: This variable examines the degree to which the minority is excluded or included by the political majority. Participation of the people, the third variable, identifies different practices of direct participation in the planning and budgeting process, while the fourth variable represents administrative

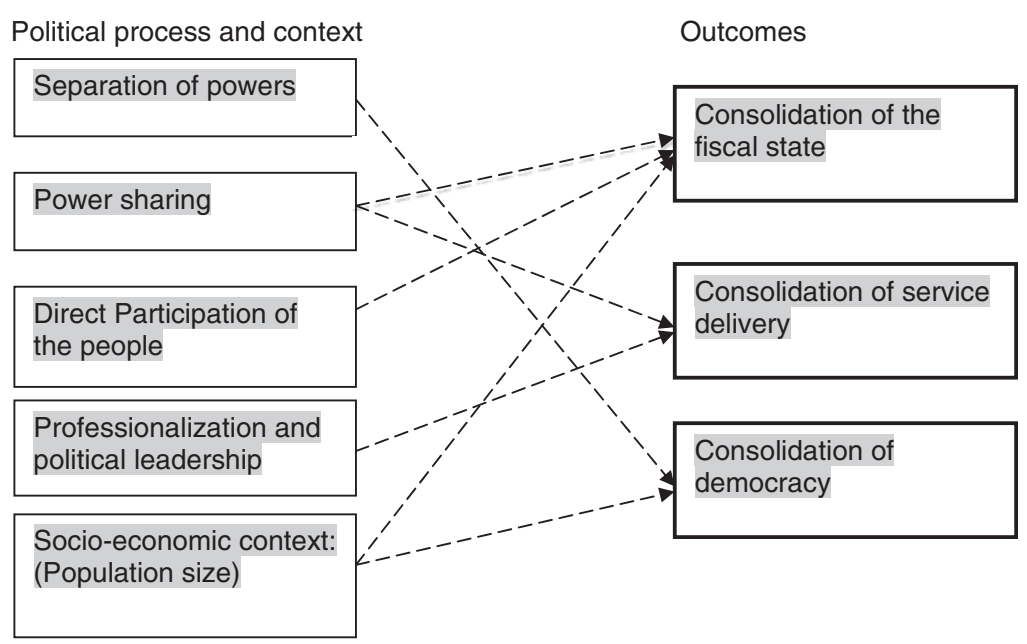

Figure 1 Basic model of consolidation. 
professionalization and the quality of political leadership. The fifth and last variable takes into account differences in socio-economic contexts as a consequence of the variation in population size in the cities of Mozambique's Autarquias.

Along this basic model, I first discuss the three issues of consolidation and present the empirical findings on the outcomes for each of the three dependent variables. Likewise, I present results of the empirical investigation on the local politics and their socio-economic context and develop hypotheses regarding the influence of the five independent variables on institutional consolidation. This prepares the field for a comparative analysis of the progress of consolidation in the Autarquias: The test of the hypotheses embedded in the causal model will give answers on the question why certain Autarquias perform better than others.

The analysis of political development is based on twelve of the thirty-three Autarquias: Chimoio, Beira, Dondo, Ilha de Mozambique, Mandlakaze, Manica, Manhiça, Matola, Montepuez, Nacala, Nampula, and Xai-Xai. The selection was based on the following criteria: First, it seemed appropriate to include all geographical regions of Mozambique, the Centre, the South, and the North, representing historically the three corridors leading from the coast to inner regions, and differing in culture and language. Second, the sample was designed to include both larger cities and smaller district towns. Finally, the sample needed to include both governing groups of the Autarquias, the Frelimo, as well as Renamo. Together with two native assistants, I visited these Autarquias in June and July 2005. In each municipality, we interviewed the Mayor, the Head of Finance, a member of the opposition party and a representative of traditional or citizen based organizations. Besides the interviews (forty-eight from the local representatives and about ten from state authorities and foreign donors), official documents and statistics as well as materials from the international donors were included in the empirical investigation. Data from interviews and documents are synthesized in the following Table 1.

\section{Outcomes of Decentralization}

\section{Fiscal consolidation}

According to Moore (2001), the successful development of constant and substantial revenue to finance its own activities is the decisive factor for a consolidated and sustainable modern State. For developing countries-and especially those of SubSaharan Africa-Moore identifies five main difficulties. First, most developing countries are poor and have only a small proportion of their workforce in formal economy sectors, drastically reducing the state's capacity to obtain a surplus from its citizenry. Second, as many African States have been created top-down and in a rather artificial way, their effective control might not reach the peripheral countryside. Third, natural resource exploitation in the hand of the developing state, 


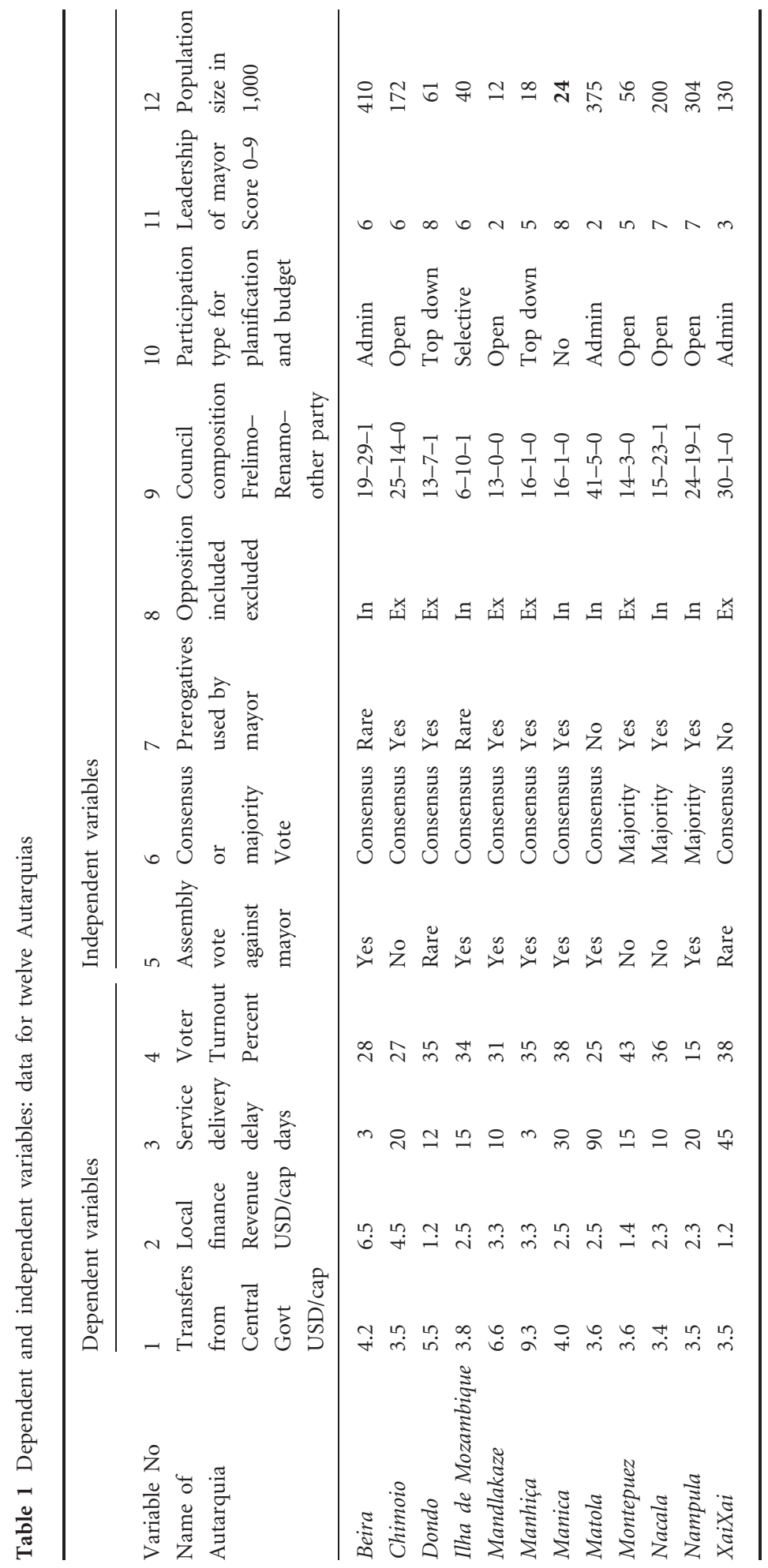


as well as budget support from the international community can diminish the will of the government to levy taxes. Fourth, there is tax resistance and tax evasion because people are simply not accustomed to paying taxes or because authorities are not trusted. Finally, unearned state income and, in some circumstances, foreign aid make the regime less dependent on its citizens and may diminish the authorities' responsiveness.

The literature on fiscal decentralization (Oates 1998, Tanzi 2000, Manor 1999) has recognized the importance of development of a state's own fiscal resources, not only for the central state but also for its sub-national units. This is particularly true when sub-national units are granted substantial political autonomy, competencies and powers, implying their own responsibilities. To formulate this in another way: real political autonomy of municipalities exists only to the extent to which these municipalities are able to finance their services through their own revenue.

Communal authorities often claim that their people are too poor pay taxes. In many cases, though, it is not poverty of the people but mistrust in local authorities making the levying of taxes unfeasible. Thus, the fiscal consolidation of the state needs trust in the sense of Putnam (1993). Moreover, it requires a learning process unfamiliar in many young countries: People have to become aware that public goods are gifts neither of foreign donors nor of "big men" but the counterpart of the contributions of every citizen as a tax payer. Thus, "ideal consolidation" is achieved if the local community can pay for a substantial part of its public services and goods.

The empirical finding is that Mozambique's Autarquias have not (yet) realized the "ideal" fiscal consolidation mentioned above. They are still dependent on subsidies of central government, ranging between 3.4 and 9.3 USD per capita per year (variable 1, Table 1). In ten of twelve cases, this is more than a municipality's own local revenue (variable 2). Yet, the Autarquias are making progress in developing their own fiscal revenue to gain independence from subsidies. At the time of our investigation, revenue per capita varied from 1.2 to 6.5 USD per capita per year, corresponding to between 0.6 and 3.3 percent of an average annual income of about 200 USD (variable 2, Table 1). With revenues of 6.5 USD (Beira) and 4.5 USD (Chimoio), two larger cities are earning substantially more of their own revenue than received as subsidies from central government in Maputo.

Local authorities' fiscal policy consists of two main elements:

- Most municipalities use their competencies to expand their financial revenue of existing taxes or to introduce new taxes, such as a personal and a property tax, service fees, market tax, or taxes for other economic activities.

- Local tax systems have undergone some improvements. Some Autarquias, for instance, revised all the necessary registers, modernized their cadastre which is the basis of local land use tax, or even put up an electronic cadastre system. 
In general, we observed high levels of awareness for fiscal policy. Mayors no longer rely solely on monies from central government or from donors. Often, subsidies arrive late and authorities feel the necessity of developing their own revenue, experiencing first-hand that local autonomy depends directly on the ability to acquire more financial independence. Local authorities also realize that increased revenues depend on the trust of the citizens. To accomplish this, they initiate the necessary social learning processes. This is best illustrated by the example of the personal tax. Each person having a formal job between the ages of eighteen and sixty pays this tax. Community Leaders collect these taxes at the lowest level of the bairros. The amount of $15-25,000$ Meticals (0.8-1.5 USD) is small but the tax is perceived as a learning experience: Community leaders tell citizens that without their contribution, there will be no local services. This is a new experience for those who believe that public goods are free and cost nothing. We were told several times, "If people learn that it is their money allowing for service delivery, they develop ownership, interest in participation and want to control the authorities." This practice and its message can be considered an important step in the development of a civic culture for a functional and legitimate local state.

\section{Quality of public services}

Decentralization is said to bring the state "closer to the people". An important argument for this claim is that people can better express their preferences for public goods and that local administrations can provide these goods for the local community more effectively than can central authorities. In our case, evaluating service delivery was difficult because we did not have absolute standards to indicate "good" service delivery. Comparing the Autarquias was especially problematic since the kinds of public services and goods vary considerably between a small rural commune like Mandlakaze (population 12,000) and an expanding industrial city like Matola with a population of nearly 400,000. Moreover, the aspiration level for public goods depends on the citizens' preferences and possibilities for paying taxes. Thus, in order to measure quality, I concentrated on two aspects of the service delivery process. The first derives from governance standards: We asked if there is a public tender or procurement process for street repair works, and whether it leads to open competition. The second relates to delays for typical permits given in both small and big municipalities, either to construct a private house or to open a small commercial shop with up to five employees.

The existence of public tenders does not vary significantly across municipalities and is therefore not shown in Table 1. Most heads of finance confirm that for bigger works, there is a public tender. Some of them complain that there is no open competition due to interference from district or province authorities. Not all contacts with "upper" authorities are negative, however. We learnt from small 
municipalities that they "hire" district work forces for local purposes with cooperation advantages for both sides.

Delays for permits to construct houses or to open small shops, however, vary considerably from a few days to two months (variable 3, Table 1). This means that the political will and the technical efficiency of bureaucracies to deliver services to their citizens vary greatly. We do not have an absolute reference point, but compared to similar administrative procedures in OECD countries, the short delays of the best Autarquias are remarkable. What is most compelling, however, is the valuation placed by interviewees on general output efficacies for local institutions. All interviewees, including representatives of the opposition and traditional authorities, agreed that the creation of the Autarquias resulted in substantial improvements to local service delivery.

Nevertheless, interviewees cited some problems in local service deliveries. Renamo representatives complained that they were seriously discriminated against in obtaining permissions from a Frelimo-controlled authority. In general, Renamos would have to pay more, wait longer or were completely denied services. Their solution was to hire a third person not known as Renamo, and thus could obtain permission or other services required.

\section{Democratic consolidation}

According to Schneider and Schmitter (2004:61f), consolidation of democracy can be defined as "the processes that make mutual trust and reassurance among the relative actors more likely. That, in turn, makes regular, uncertain yet circumscribed competition for office and influence possible. It institutionalizes the practice of "contingent consent", namely, the willingness of actors to compete according to pre-established rules and, if they lose, to consent to the winners the right to govern-contingent upon the right of the losers to compete fairly and win honestly in the future".

At a national level, Mozambique has had difficulties in the realization of fair elections. After three elections, change of power between the government and its opposition has not occurred.

In 1998, Renamo boycotted the first local elections. The boycott was organized as a form of protest and system opposition, leading to a low voter turnout of only 17 percent, and was interpreted as a clear sign of disenchantment with democracy. In the 2003 elections, without a Renamo boycott, voter turnout was considerably higher at 27 percent; although still lower than for national elections held in the previous year. ${ }^{2}$ In some districts, serious irregularities were reported. Renamo voters, especially in smaller municipalities of the South, were intimidated or even threatened. According to a foreign observer, elections were "not fair" (Braathen 2004:18). Obviously, local democracy suffered the same kinds of voting practice 
shortcomings observed at a national level. Despite this, a comparison of local elections in 1998 and 2003 shows some improvement: In contrast to the first elections, Renamo participated in 2003, and won for the first time in five out of the thirty-three Autarquias (three out of twelve in our sample). In one of the Autarquias, elections ended in a tie, leading to a form of power sharing between the two parties. In places where political change took place, it was mostly attributed to a negative reputation in the past related to Frelimo's political management. Voters learned to differentiate between national and local politics. This is especially the case in Beira where people continued to vote for Frelimo in the 2002 national elections, but 2003 voted out the local Frelimo government, having lost the confidence of the same electorate. These power changes were accepted by all of the formerly ruling Frelimo. All together, more competition, a higher voter turnout than 1998, and a successful change of power in a number of Autarquias indicate steps towards consolidation of democracy. According to Schneider and Schmitter (2004:68), change of power should occur a second time to be a valid indicator of democratic consolidation. Even so, the Autarquias allowed for first changes in power, not feasible at the national level in the past.

There are considerable local differences in voter turnout. In the twelve Autarquias observed, voter turnout ranged from 15 percent to 43 percent, with a median of 33 percent (variable 4). In some of the Autarquias, 2003 turnout was lower than 1998, when Renamo boycotted the elections. Braathen (2004:11) partly explains lower turnout by local events of discrimination, creating a "withdrawalfrom-politics-effect". In contrast, Autarquias with voter turnout well above average were those where elections were salient and led to a change of power (Ilha de Mozambique or Nacala). Thus, we may take voter turnout as an indicator of democratic consolidation-not for democratic consolidation in general sense, but useful in comparing local differences with respect to the legitimacy of competitive elections or to disenchantment with democracy.

\section{Political Processes: The Use of the New Institutions}

Political actors can use new institutions in different ways. They can accept or reject them, use the polity in a legitimate sense of promoting public interest or abuse them for their own personal purposes. Political elites can extend the people's participation or keep civil society out of the decision-making process, and either include or exclude the political minority. These politics influence the development of institutions. In the following, I conceptualize and describe such politics in the form of five variables: Separation of powers, power sharing, direct participation, professionalization and political leadership, and their socio-economic context. I develop the hypotheses postulating why and how these politics, as independent variables, contribute to one or more of the three elements of institutional 
consolidation as dependent variables. As illustrated in Figure 1 (Basic model, above), I do not presume that each of the five independent variables has effects on all three elements of consolidation but concentrate on main effects feasible from the context. For instance, I observed that direct participation was mostly used for the planning and budgeting process. Thus, I propose a positive effect on fiscal consolidation but leave out possible secondary effects of improving democratic consolidation. The reason or this is simple: The main interest of the study lies in a parsimony model explaining service quality, fiscal and democratic consolidation and their differences in the twelve Autarquias. The hypotheses set the stage for the comparative analysis presented in the next section, to understand why in the process towards consolidation, some of the Autarquias are performing better than others.

\section{Separation of powers}

Checks and balances, and the separation of powers are founding principles of constitutionalism and governance. They have been provided for in the institutional design of Mozambique's local polity. The Autarquia resemble a presidential system in which the Mayor freely nominates his cabinet. The Mayor can nominate some members of the municipal assembly, but the other members of the Assembly are elected by the people and are therefore independent from the executive. Despite the conventional wisdom of these checks and balances, their proper functioning was not clear at the beginning. Nuvunga (2004: 18ff) mentions a typical problem of inconsistency between symbolic and factual hierarchy: How could a Mayor accept to be sworn in by the President of the Municipal Assembly? Following the former perception of state hierarchy, the President would refuse and appeal to a higher authority at the provincial level. The prerogative of the President of the Assembly to swear in the Mayor makes sense only under the aspects of local autonomy, and under the premise that the legislative body is more legitimate than the executive organ. If however the President of the Assembly has to be considered a "higher" person than the Mayor, why does he get neither a salary nor a four-wheel-drive-car like the Mayor? The questions illustrate that American or European institutions have many assumptions which are not self-evident in another cultural context.

In the traditional liberal view, the separation of legislative and executive competencies was perceived as an instrument to limit the power of state authorities. In a modern reading, we see the separation of powers more as an element of governance to prevent corruption or another illicit use of public resources. Finally, a functioning separation of powers is a favorable condition for the legitimacy of a ruling party or a political regime, formulated in the following hypothesis:

H1: Separation of executive and legislative powers is favorable for democratic consolidation. 
Despite identical legal structures, separation of powers in the Autarquias differs in political practice. The presidency of the Autarquia is very strong, and it is crucial that the Assembly is able to exercise some sort of control over the executive. This is a valid indicator for the existence of checks and balances. We therefore asked our interviewees if the Assembly had voted against the Mayor in the current legislature. In more than half of the cases, the answer was "yes" (Table 1, variable 5). But many interviewees added that refusals did not concern important matters. They also explained that the Mayor's proposals were not bluntly refused, but rather, the Assembly made suggestions for further re-considerations. Those who answered "never" were very clear, at times expressing astonishment about the question. Therefore, with regard to functioning checks of balance between the Assembly and the Mayor, the picture is mixed. While in a good part of the Autarquias, separation of powers has become part of the new political culture, in others the fusion of power is prevailing.

\section{Political power sharing}

As already mentioned, Mozambique remains a segmented and deeply divided society. For these societies especially, Lijphart's $(1984,1999)$ theories propose that the consensus model of democracy offers better chances for conflict resolution than the prevailing majoritarian or Westminster model of democracy. In their comparative analysis, Linder and Baechtiger (2005) have shown that power sharing generally has a positive effect on democratization in developing countries of Africa and Asia. Moreover, under conditions of clientelism, power sharing may have an additional significance, namely that we can expect non-ruling groups to be less excluded from the distribution of public goods or less discriminated against with regard to public services. As Mozambique's Autarquias are characterized by deep societal cleavages and conflicts, we expect power sharing to be highly relevant as a factor of consolidation.

In the empirical investigation, we analyzed two elements of power sharing more closely:

- Consensus style within the Cabinet: This element is measured by the degree to which the decisions in the local executive are taken unanimously or by majority vote (variable 6). As the Mayor nominates his cabinet and can dismiss its members without any intervention from the Assembly, he theoretically holds all the executive power. A consensus style of the Mayor is therefore also an indicator of the degree to which the executive Council is a real deliberative organ or just a decorating element.

The findings are instructive. In all but one of nine Councils ruled by Frelimo, the decision-making was characterized as a consensus-seeking process. This may correspond to a widespread African tradition of consultative 
decision-making and is motivated by the wish "to have all people in the boat", as described by several Mayors. The three Renamo Councils, on the other hand, prefer majority voting. In both modes of decision-making, however, consultations of external actors are common. Asking about the prerogatives of the Mayor (variable 7), we mostly got the answer that the President would use them rarely and rather in "technical" than in "political" matters. I therefore conclude that most councils fulfill their function as deliberative executive organs.

- Inclusion of the opposition: This element is measured by whether or not members of the opposition were allowed to participate in Committees of the local legislature (variable 8). Indeed, inclusion or exclusion in Committees of the Assembly makes a great difference because Committees constitute the bodies in which the local problems of public interest are defined, options of action developed, and where legislative decision-making is shaped.

The findings differ greatly from those on cabinet consensus style. Power sharing is practiced in half of the twelve Autarquias. But as seen from the partisan majorities in the Councils (variable 9), Renamo always practices inclusion of the opposition, while Frelimo, in six of nine cases, excludes the opposition from the Committee process. This fits into the general pattern of relations between Frelimo and Renamo. Both political parties still stand for the names and for the past organizations that fought a civil war that cost the lives of many young men from both sides in every village, more than 100,000 in all. Despite a remarkable peace process since 1992, many wounds are not yet healed. Both parties deeply distrust each other. Each party accuses the other of committing electoral fraud; each party pretends that the other is corrupt while corruption cannot be found in their own ranks.

- The strong asymmetry in the practice of power sharing has to do with the dominant position of Frelimo over Renamo and requires further explanation. Frelimo, the ruling party, is said to pursue its policy of exclusion against Renamo on all political levels. In Frelimo ruled municipalities, we could not find Renamo officials in the local administration - a fact frankly admitted to by Frelimo leaders. As the ruling authority in the country, Frelimo sees no advantage in the politics of inclusion. The reverse is not the case. In Renamo ruled municipalities, we can find Frelimo party members in higher ranks of the administration, as experts for Renamo politicians or even as members of the Council. If Renamo seeks cooperation, or even power sharing with Frelimo, this has certainly to do with the dominant position of Frelimo-politically, economically and socially. For many reasons (for instance: having better relations with the Frelimo dominated district or central government authorities) cooperation, rather than exclusion, may be a wise policy for Renamo. 
- Asymmetry is also found in the valuation of democratic change. Renamo representatives coming to power in 2003 through local elections welcomed the change between government and opposition as a principle that is healthy, even necessary for democracy. Frelimo, and not only those who lost power in the last elections, cannot see any positive point in the loss of their political majority (which is understandable) and would deny any value of the regular change of roles between government and opposition (over the long-term, this is less understandable).

Thus, we find an ambivalent situation: Decentralization has given greater chances for the opposition to come into power but does not necessarily lead to inclusion and political power sharing. As the Frelimo majority practices inclusive politics only exceptionally, conflict resolution on the basis of negotiation and compromise does not happen in most municipalities. Asked about the development of relations between Renamo and Frelimo, Renamo representatives are deeply skeptical, if not pessimistic. They feel that relations could even deteriorate. Their personal histories reveal common patterns of discrimination and exclusion. Frelimo would hardly admit to these accounts but their view is far from unanimous. Some pretend that social peace is improving; others say, "we have forgiven but not forgotten the past," and a third group will admit that like their opponent, social peace is not improving. From the perception of the directly involved parties, perspectives for social peace are anything but bright. Even so, there is a remarkable consensus on the general issue of local institutions and development. Both sides want economic development; both consider the experience of decentralization and of the Autarquias as positive. "On the local level, it is practical policy that counts, not ideology" was often heard as a comment on the fact that there are no fundamental differences on the development projects of the municipality.

In sum, however, we must conclude that despite the partial practice of power sharing, decentralization seems to have had little integrating or pacifying impact.

As the politics of inclusion are asymmetric but practiced by both political parties, we may ask about their impact on the consolidation issues of our study. Drawing from Lijphart's power sharing theory, we expect positive effects on all three issues and propose the following hypothesis:

H2: Politics of political power sharing promote higher quality of services, higher fiscal revenue and higher democratic consolidation than majoritarian styles of politics.

\section{Participation of citizens' organizations}

It has become widely accepted that participation of citizens beyond formal elections, especially at the local level, is helpful for the development of democracy 
and governance. Politicians and scholars, for a long time preoccupied with formal political parties, today underline the importance of NGO's, peoples' organizations, and of traditional leaders or authorities as actors on the local stage. Sub-Saharan countries do not have a long tradition of democracy but rely on a rich cultural heritage of traditional authorities and organizations. These organizations still perform many "public" tasks. They are influential especially in smaller cities, have a strong legitimacy, and can be seen as actors having multiple intermediate functions between the people and the formal political authorities (Oluwu and Wunsch 2004, Lutz and Linder 2003).

In Mozambique also, traditional and citizen-based organizations play an important role in local politics. Traditional society, as in other sub-Saharan countries, is participative but distrusts authorities not embedded in a personalized social fabric. Informal politics may overrule formal institutions (Hyden 2006) - as it does in Mozambique. As Nuvunga (2004:23) puts it, there is a risk that the "modern" institution of the Autarquia, rather than being accepted by the people, leads to a divide between the elites and the people. In this context, direct participation may be helpful for building a bridge between traditional and modern institutions, and between informal and formal politics as well.

The interviews reveal complex structures of participation. One can distinguish at least three forms of interaction between civil society and the local state:

- Participatory planning and budgeting processes are innovations of the Autarquias and their authorities, but used differently in each. In the smaller municipalities, "assemblies" of traditional organizations practice the most authentic form of participation. Foreign donors have stimulated participatory budgeting. One of them, the Swiss Developing Co-operation SDC, combined its local budget support with participatory devices allowing illiterate citizens to express their preferences among different budget proposals. In some municipalities, participation is informal, at others it is formalized, often in ambiguous ways: If the Mayor heads a "participative forum," participation can end up in a top-down mobilization process rather than exploring the peoples' needs. In bigger cities, organizations of civil society are less involved. Instead of citizen participation, we find different forms of consultation of the different divisions of a professionalized administration.

- Where industrialization has not taken ground, the family is still the most important institution. It provides for all the basic societal functions of production, (re-)distribution, security, and reproduction. The family therefore is the secure haven for individuals. An extended family system's social networks often fulfill tasks of general interest, information on HIV-AIDS or civic education for instance. In many places, churches care for the poorest and are more important, while municipalities promote coordination between the various religious communities. 
- Societal organizations articulate their needs and desire to be heard by the authorities, and the reverse is true as well. Authorities mobilize societal organizations for their projects, policies and tasks. Such is the case with the personal tax, often collected by the "Community Leader" in the bairros. Community leaders also "select" their clientele and tell district authorities who is in need of social services-and who is not. As many of today's community leaders once were party secretaries of the ruling Frelimo, one can see the ambiguity of their role. They can be considered either as speakers of the "bottom up" organizations of the bairros, or as representatives of the finest capillary of Frelimo's social top-down control.

Our empirical finding is that open bottom-up participation in the planning or budgeting process is realized in half of the Autarquias visited (variable 10) For this form of direct participation, I propose the following hypothesis:

H3: Participation of traditional and societal organizations in the planning or budgeting process leads to better consolidation of the fiscal state.

\section{Professionalization and political leadership}

The efficacy of a modern state depends largely on the quality of its administration. These qualities can best be described in terms of the Max Weberian ideal of "rational order": Administration is both functionally specialized and hierarchical. Personal interests are separated from the duties in office; the administrative staff is professionally selected, trained, and promoted. We did not have the means for an inquiry in each of these dimensions and therefore had to concentrate on a few pertinent items. We asked for the professional career of the interviewees, for the training of the staff, for the way applicants were selected and hired. Moreover, we tried to identify the existence of corruption. Our investigation cannot claim to present valid results of this last issue. We learned quickly that blaming the political opponent to be corrupt is part of the daily ritual. Consequently, both political parties systematically denied corruption in their own party. From international reports one can learn that there is considerable corruption in Mozambique ${ }^{4}$ but we could not learn anything about differences between the central and the local level or between different municipalities.

Regarding professionalization, we must first consider the variation in size among the local governments in Mozambique: In small cities like Mandlakaze (12,000 inhabitants) or Manhiça (18,000 inhabitants) the administration consists of a handful of people only, and the mayor is an entrepreneur in agriculture. Large cities like Matola or Beira with around 400,000 inhabitants count a staff of several hundred professionals, and their full-time Mayors have university degrees. As everywhere, professionalization and specialization depend on the 
size of bureaucracy. This can also be observed with regard to the hiring of personnel. A formal public tender is made only in larger municipalities. Great effort was undertaken in training both administrators and politicians. The Ministry of State and most international donors regularly organize training and courses in all pertinent subjects, such as planning and budgeting, the use of computers, political skills, institutional knowledge and formal administrative procedures. All municipalities, regardless of their size, could and obviously did profit from these various offers to build their capacities. ${ }^{5}$ Special effort was put into capacity building programs for administrators without secondary education. In the training system of both political and administrative elites, less discrimination exists against Renamo compared to that of leading posts, for which Frelimo do not hire Renamos. Since the beginning of the Autarquias in 1998 there has been a constant, consistent and competent effort to train political elites and administrators of all levels. Local political leaders are aware of the importance of building capacities within their local staffs. While professionalization is on its way, the same can be said neither with regard to the de-politicization of the administrative staff, nor with regard to corruption.

Lack of valid data did not allow a systematic comparison of these dimensions of professionalization. We could, however, compare the quality of political leadership. In a situation like Mozambique's Autarquias, political leadership is particularly relevant. In young institutions especially, the development of the administration, its functioning and culture depend upon leaders with managerial, social, political, and communicative skills. We therefore tried to identify the political leadership of the twelve mayors through the evaluation of two external experts on three characteristics. We asked them to rank the influence of the Mayor within his own party, to evaluate his social and communicative skills, and finally to provide an appreciation of his administrative capacities. Variable 11 gives the aggregate value of these three items, each ranging from very weak (0) to very strong (3).

There can be many subjective elements in such an evaluation. However, we found a rather strong variation of perceived leadership. The observed values on our 0-9 scale range from 2 to 8 . Moreover, the high quality of leadership of some mayors was even recognized by opposition representatives. I therefore think that the evaluation is valid for our purpose. As strong leadership should transform into quality of public services, the hypothesis is the following:

H4: Strong leadership leads to better service quality.

\section{The socio-economic context}

The Autarquias of our sample differ in population size from 12,000 to 424,000, a factor of about thirty-five (variable 12). While population size as such is not 
relevant for democratic or state development, the corresponding socio-economic context certainly is. In our case, "large" and "small" municipalities differ in most socio-economic characteristics. A sedentary and relatively homogeneous population characterizes smaller Autarquias. Their inhabitants derive their livelihoods mostly from farming, and the structures of traditional organizations are largely intact. Large cities must cope with much more heterogeneity. Part of the population earn salaries from private industry or public agencies, part make their living for good or for bad in the informal sector, and some are migrants or city dwellers without jobs. Although large cities rely more on the resources of modern administration and have better chances to collect fiscal revenue, they must also cope with considerably more difficulties in the management of their public sector and the development of a functioning democracy than smaller, more rural municipalities. Good mass media are the exception, and authorities may encounter difficulties in establishing reliable communication and in the development of civic culture. Mutual trust beyond family structures may develop more easily in small communities than in larger cities where traditional family structures are deteriorating and new social relations difficult to establish. The cleavages between modernity and tradition and between different ethnic groups within the same community may be much deeper in larger than in smaller cities. Thus, I propose hypothesis 5 as follows:

H5: In the short time of their existence, Autarquias with a smaller population size have more difficulties to collect fiscal revenue but better chances to develop democratic consolidation.

\section{Why Some Municipalities Perform Better Than Others}

In the following, we test our five hypotheses on the State and on democratic consolidation by means of a qualitative comparative analysis (Ragin 1987; 2000). QCA analysis is well suited for studying complex causality in the context of low numbers of cases and many variables, as we typically find in urban studies (Sager 2006) or in the De Meur and Berg-Schlosser (1996) study on the survival of European democracies. Unlike some statistical methods, QCA is not based upon co-variance calculations but uses Boolean algebra to identify possible combinations of factors leading to a defined outcome. In other words, the method helps to eliminate out the many variables which do not influence the outcome, a task that is sometimes even more important. In the basic form of QCA analysis, cases are coded into binary conditions as in Table 2 and then entered into a truth table, including dichotomized versions of the independent and dependent variables. Truth tables create rows with all logically possible combinations, and Boolean algebra identifies additive and multiplicative formulae minimized to the most parsimonious solution of an outcome. In this study, two factors-presence of 


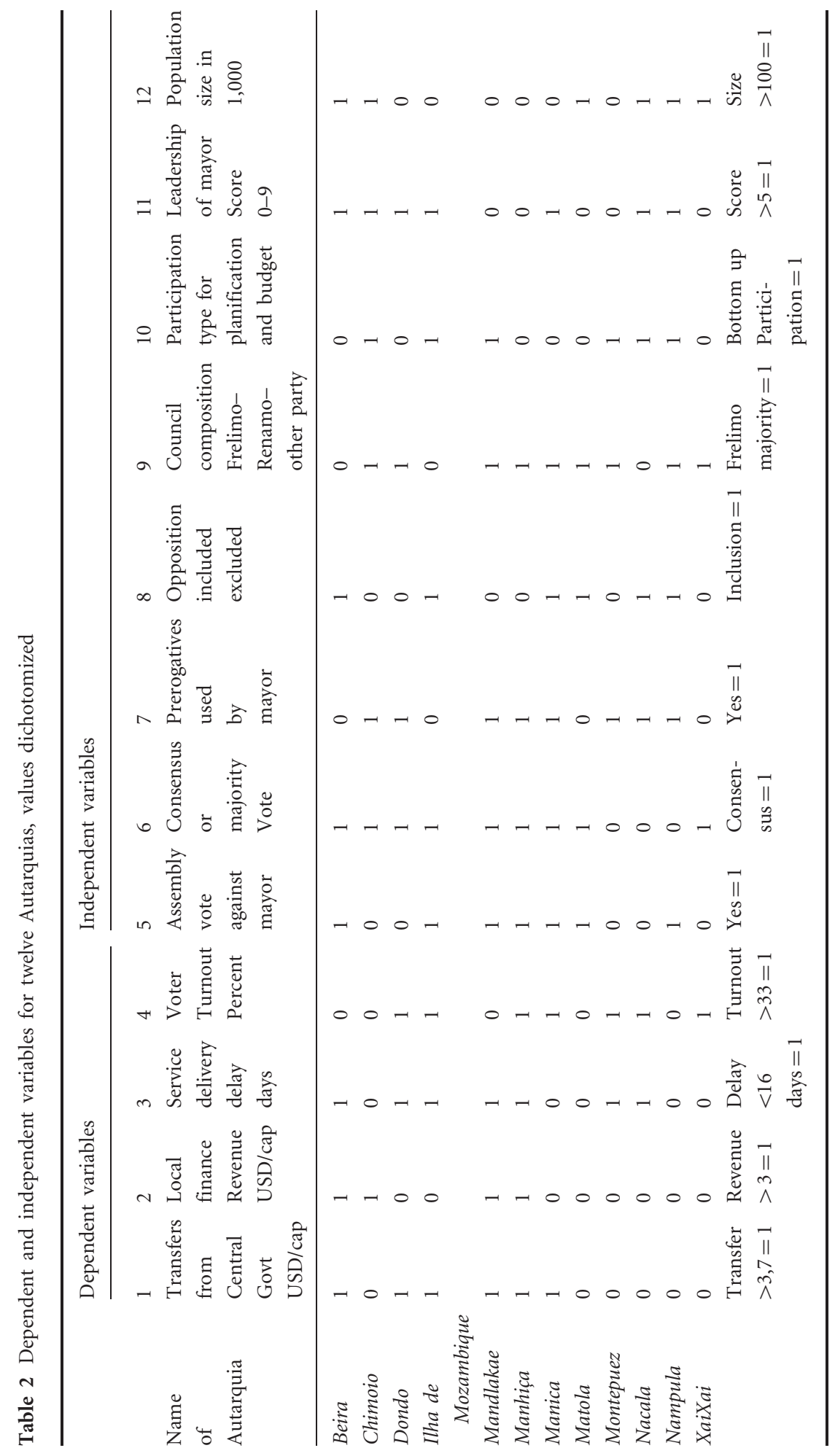


Frelimo and population size-provide basic contexts in which the role of additional factors for consolidation is evaluated. The selection of the additional factors was basically theory-driven: we chose those factors for which we postulate a causal effect in our hypotheses.

\section{Fiscal consolidation}

As explained above, consolidation of the fiscal state is measured by the degree to which a community has the capacity to collect own revenue. Causal effects are postulated in the two basic variables mentioned above, Frelimo or Renamo regime and population size. The additional factors include participatory planning and budgeting as well as opposition inclusion, which we found theoretically relevant for development of revenue in our hypotheses. QCA analysis offers the following two sets of conditions for high financial revenue:

frelimo ${ }^{\star}$ OPPINCLUS ${ }^{\star}$ participplan ${ }^{\star}$ POPSIZE + FRELIMO $^{\star}$ oppinclus $^{\star}$ PARTICIPPLAN $^{\star}$ POPSIZE. $^{6}$

First of all, we note that the capacity to develop local revenue is a monopoly of neither Frelimo nor Renamo. Financial consolidation can be achieved under the regime of Frelimo and Renamo as well, but is always higher in larger municipalities. We do not know the exact reason for the better fiscal performance of larger cities but would guess that they are rather economic (higher economic level, more industry, more services in the formal sector) than political (big cities do not get more transfers from central government). With regard to the other factors of success, we notice a trade-off of sorts between power sharing and direct participation: Frelimo's successful mobilization of resources rests upon participation without power sharing, while it is the opposite with Renamo: Good results can be achieved with power sharing while renouncing direct participation. Both results are unexpected because they partially contradict our hypotheses $\mathrm{H} 2$ and $\mathrm{H} 3$; with regard to fiscal consolidation, Frelimo achieves better results without power sharing, and Renamo is more successful without participation.

The trade-off between power sharing and direct participation is informative. The QCA-analysis reveals that these two elements, embedded in partisan strategies, can perform different functions. For successful consolidation, they can even substitute for each other. For Frelimo, with a dominant strategy of exclusion, direct participation makes sense in addressing its own clientele, which may revitalize the political legitimacy of its long-standing majoritarian regime. It is obviously a successful means for mobilizing higher resources, but in the majoritarian setting can be limited to a partisan strategy. ${ }^{7}$ Direct participation is also coherent with Renamo's strategy but then plays another function. It may be credible for a policy of inclusion but then must address Frelimo's clientele as well. 
"Inclusive participation" is obviously not helpful for resource mobilization, which rather benefits from the cooperation with the entire political elite. If we accept this trade-off of power sharing and direct participation, both strategies for success seem to be coherent.

\section{Quality of public services}

Besides the two basic variables of Frelimo/Renamo regime and population size, our hypotheses imply the inclusion of the following variables: leadership, opposition inclusion, and separation of executive/legislative power. QCA analysis shows that there are two pathways to effectiveness of public services:

FRELIMO $^{*}$ oppinclus $^{*}$ popsize +

frelimo ${ }^{\star}$ OPPINCLUS ${ }^{\star}$ LEADERSHIP

As with consolidation of fiscal revenue, service quality can be achieved under Frelimo and Renamo majority as well but under different constellations. Power sharing is a successful way for Renamo, but not for Frelimo who practice this strategy only in three of nine cases. The fact that Frelimo performs better without power sharing speaks against hypothesis $\mathrm{H} 2$ again. It reveals that in the asymmetric incentives for co-operation, the different strategies of Frelimo and Renamo are not only the rational choices of a different style of politics but effective for achieving higher service quality (and revenue as we have seen).

Population size, the indicator for the socio-economic context, is relevant: Frelimo achieves better service quality in smaller cities. This can be interpreted as a consequence of the participative strategies of the Frelimo regime, which might be more effective in smaller communities. For the Renamo-Autarquias, another criterion is important for the efficacy of the local state: the one of political leadership. Service quality and political leadership go hand in hand. Separation of powers, however, is not relevant in either case.

\section{Democratic consolidation}

Finally, we look at our indicator for local differences of democratic consolidation, voter turnout, varying considerably from 15 percent to 43 percent in the 2003 elections. The QCA analysis involved the two basic variables again, Frelimo/ Renamo regimes and population size. According to the hypotheses, two political variables were added, namely opposition inclusion and separation of powers. We find one single configuration only for higher voter turnout:

OPPINCLUS* ${ }^{*}$ popsize

This configuration suggests that high turnout is observable in small Autarquias where power sharing is practiced. As expected in hypothesis 5, higher democratic 
consolidation in small towns may have to do with better conditions for voter mobilization, with higher social control in smaller communities and the more "personal" character of African politics (Hyden 2006:137). This contrasts with the conditions found in large cities, characterized by high social heterogeneity and poor mass communication. Theoretically even more important is the effect of political inclusion. With regard to democratic consolidation, power sharing is an independent factor for Frelimo and Renamo regimes, in contrast to our findings for revenue and service quality. This systematic effect corresponds to findings of a comparative study of Linder and Baechtiger (2005), namely that power sharing may have a positive effect on the establishment of democratic institutions. In Mozambique's Autarquias, the rules of the game seem to have more legitimacy if the majority renounces the principle of "winner takes all" and political exclusion. This interpretation is highly plausible at least for Frelimo-Autarquias. For Renamo-Autarquias, we do not know to which degree higher voter turnout in 2003 was the effect of salient elections removing Frelimo from power. Contrary to expectations, separation of powers (hypothesis H1) did not influence democratic consolidation.

\section{Hypotheses reconsidered}

- Separation of legislative and executive powers, expected to play a significant role in democratic consolidation, did not play a significant role.

- For our second hypothesis on Power sharing, we must differentiate. Under the asymmetric use of the politics of exclusion (Frelimo) and inclusion (Renamo), power sharing cannot develop its main beneficial effect of overcoming cleavages through mutual recognition of political antipodes, or by means of negotiation and compromise. Moreover, the proposition that inclusive politics promote better development of fiscal revenue or service delivery must partly be revised: Comparative analysis shows that for Frelimo regimes, it is not the case. Pure majoritarian Autarquias perform better than those practicing power sharing. While both findings can be interpreted as empirical evidence speaking against theory, we note an important feature of power sharing in all municipalities, Renamo or Frelimo: Power sharing is consistent with a higher voter turnout, suggesting that the policy of inclusion has a positive effect on the credibility of democratic institutions and their legitimacy.

- Observations on direct participation in the planning and budgeting process lead to some similar conclusions. As a partisan strategy, participation improves revenue in Frelimo municipalities but does not make a difference in Renamo Autarquias. Direct participation may improve system legitimacy in all places but play different functions. In exclusive Frelimo regimes, it has its rationale as a partisan strategy, used as a bottom-up and top-down device as well. 
As a bottom-up strategy, it serves to know better the needs of its clienteles and successfully mobilizes them for higher revenue; as a top-down strategy, it is rather an instrument of the elite to realize their own political projects. Renamo's strategy of direct participation, in order to be coherent with its policy of inclusion, must be open also to all people and their organizations. Integrating all different interests may be more difficult than finding compromise with the elite of Frelimo; this might be the reason why direct participation, for Renamo regimes, does not improve success in raising revenue, thus illustrating an ambiguous nature of direct participation found beyond Mozambique's' Autarquias.

- One of the most interesting findings of the QCA analysis is the interaction of power sharing and direct participation. Both can be seen as part of partisan strategies reflecting different structural situations within their respective political parties: Renamo, as the socio-political underdog outside its local regime, uses inclusion of the Frelimo elite as a means to compensate for weaknesses of external influence and power. Dominant Frelimo, on the other hand, relies on a strategy of direct participation to stabilize or renew the legitimacy of its longlasting countrywide "one-party-regime" and of the local Frelimo-rule as well. Both strategies succeed with regard to service quality and revenue of the local State, suggesting that in a way, direct participation and power sharing substitute for each other.

- The fourth hypothesis about the positive effects of political leadership on service quality was found to be true but only under the specific conditions of a Renamo regime. One explanation is that for Renamo, leadership is more important: Sharing power with the dominant Frelimo political and administrative elite needs particular leadership skills while the politics of Frelimo regimes can rely upon their better established social and political networks.

- Population size is indeed a factor for democratic consolidation as postulated in our last hypothesis. Smaller cities not only have a higher democratic consolidation, but also, under Frelimo regime, better service quality. Moreover, population size is a relevant factor for consolidation of the fiscal State but in an unexpected manner: Financial revenue is better developed in big cities. Thus, size is an important factor for all dimensions of institutional development but not always in the same sense: small populations are an advantage for democratic consolidation and service quality but a weak point for financial autonomy, while for big cities, it is exactly the opposite. In all these observations, we have to keep in mind that behind our variable "population size" we find differences of social heterogeneity, of economy and of ways of political communication. Thus, it is not the population size as such making the difference. It is rather the different socio-economic and socio-political context of the Autarquias, which could not be further analyzed in this study. 


\section{Conclusion}

In investigating new local institutions in a developing country, we found empirical evidence for three important merits of decentralization proposed by theory.

First, the new institutions have improved service quality for the people. Despite their political differences, all local actors strongly agreed upon the point that with the local autonomy of the Autarquias, service delivery had become better, quicker, more dependable, and more to the people's needs than it had been under the former regime of district administration. Despite deep divides, elites converged in a commitment to the development of their Autarquia. With the inauguration of municipalities, it has become possible for part of the population to express their preferences, formally through local elections and informally through participative planning and budgeting. All interviewees mentioned that these possibilities gave the people real chances to have their voices heard better by the authorities. ${ }^{8}$ Thus, in the Mozambique experience, decentralization meets its promise "to bring the state closer to the people."

Second, Mozambique's decentralization process provides evidence that capacities to develop local revenue have been improved. The consolidation of the fiscal state, however, is far from perfect. In order to fulfill their tasks, the Autarquias still depend substantially on transfers from central government. Even so, the result should not be underestimated. Mentalities have changed. Political elites have used their competencies to introduce new taxes. They are aware that autonomy carries with it costs and that developing revenue is necessary to reduce dependency from the central government. In the former centralist system, the experience of obtaining public services was sometimes difficult-but free. Now, with the birth of municipalities and their autonomy, citizens could express their desires far better but must also learn that these wants and needs have a price. Local authorities have been able to develop a certain degree of trust in a formal institution, which attempts to overcome the usual pattern of personalized politics (Hyden, 2006) or patrimonialism (Chabal and Daloz, 1999), and the limitations of familistic institutions (Müller 1996) in sub-Saharan countries. The message that public goods are not gratuities but the counterpart of the taxpayer's money has reached the local people. In terms of Moore (2001), this is most relevant beyond fiscal state development because citizen ownership increases incentives for effective control of the authorities.

Third, the general picture of democratic consolidation for the Autarquias is mixed. On the negative side, we find similar irregularities in the local elections as compared to those reported at the national level. On the positive side is the 2003 participation of Renamo, the minority party, after a general boycott of the first local elections in 1998. In a number of Autarquias, political change of the roles of government and opposition took place in salient elections with high voter turnout. 
Whenever these changes occurred, Frelimo accepted them. This is remarkable, considering that on a national level, the Frelimo excludes Renamo from power positions at every opportunity. Thus, decentralization provided chances for political change currently nonexistent at the national level. This is a promising step in the development of political pluralism. It remains an open question, however, if this political pluralism will have impact beyond the local level.

While we see many positive development with regard to our main questions of consolidation, the limits of Mozambique's decentralization experience should not been overlooked.

- The deep societal divide and the antagonism between ruling Frelimo and the Renamo minority are still in place. We note that during the brief period of our observations, decentralization was unable to fulfill one of its most important promises, namely to ease societal divide and conflict. Although it was conceived by Lijphart and others as an element of vertical power sharing, decentralization has to be combined much more with forms of horizontal power sharing to overcome deep societal divides, such as found in Mozambique.

- Some of our interviewees expressed the fear that Frelimo could one day withdraw completely from decentralization experience, suspending the Autarquias. In theory, as long as Frelimo holds its strong majority on the national level, it could do so. Although we prefer not to be so pessimistic, the facts remain that even today, only part of the population profits from local autonomy, as steps to increase the number of Autarquias in the rural districts have been postponed. The ruling force of the country seems less enthusiastic about decentralization than at the beginning.

- Decentralization is an institutional means only. It does not resolve the fundamental economic problems to which developing states and their societies are exposed. Under the actual rules of globalization, chances for a sustainable economic development have not increased any more for Mozambique than for many other African countries. As long as the majority of the population cannot find employment in the formal market economy, the development of a modern and democratic civil society, which can leave behind the limitations of the "economy of affection" (Hyden 2006), is not a possibility.

The QCA-analysis provided many insights, allowing us to analyze the differences in institutional consolidation within the twelve Autarquias in a systematic way and to determine patterns demonstrating better chances for success. Socio-economic context and power sharing have had a systematic positive effect on democratic consolidation. However, participation proved more ambiguous in different political settings. While mainstream theory looks at general regularities of institutional politics, our findings indicate that the same politics of power sharing or participation may have different effects in different strategies of the political parties. 
Finally, QCA shows that the three elements of consolidation-service quality, fiscal development and democratic consolidation-depend on different patterns of politics. Politics matter for consolidation- but in much more complex ways than general theories suggest.

The success of Mozambique's Autarquias may have particular significance for subSaharan countries. Oluwu and Wunsch (2004) suggest that decentralization is part of the answer to what is commonly described as the failure of the African nation state. In many ways, the Mozambique experience fits into the more general picture proposed by Basil Davidson in his famous book "The Black Man's Burden":

Development strategies in Africa, with minor exceptions, have tended to be strategies by which the few use the many for their purposes. They are uncompromisingly top-down. There is not, and never has been, popular participation in political and economic decision-making.... The cause (of the complete failure of the post-colonial nation-state) laid the failure of our rulers to re-establish vital inner links with the poor and dispossessed of this country. It was the failure of postcolonial communities to find and insist upon means of living together by strategies less primitive and destructive than rival kinship networks, whether of "ethnic" clientelism or its camouflage in no less clientelist "multiparty-systems". The key to progress ... would be found, rather, in devolving executive power to a multiplicity of locally representative bodies. It would be found in re-establishing "vital inner links" within the fabric of society. Democratic participation (as) ... mass participation, patiently evolved and applied, would be able to produce its own version of a strong state: the kind of state, in other words, that would be able to promote and protect civil society (Davidson 1992: 291-94).

\section{Notes}

This article is based on an extensive field trip in Mozambique, which could not have been realized without the support of many persons. I am most grateful to Bernhard Weimer for all of his assistance, for his wise guidance and his hospitality. I want to thank Adriano Nuvunga and Sonia Massangaia, two young Mozambiquean scholars who organized my field trip, made the fifty interviews with local authorities possible and carefully acted as interpreters. I am grateful to Rodolfo Candido, program director at GTZ in Chimoio, who was not only interested in this study but gave us a most helpful hand on the trip in the centre. My thanks go also to André Baechtiger, who, as a specialist in the QCA-methods, did the calculations with the software program. Finally, I am grateful to three anonymous reviewers and the editor Carol S. Weissert, who gave most valuable advice for the revision of the manuscript.

1. For extensive descriptions and evaluations of the institutional structures see: Weimer 2000, Weimer 2002, Braathen 2003, Matusse, Angelo, Langa Marta and Adriano Nuvunga 2003, 
Sitoe and Hunguana 2007, or the documentation of The Commonwealth Local Government Forum: The local government system in Mozambique, 2006. www.clfg.org.uk.

2. Official statistics, information from political parties and estimations of foreign observers on voter turnout for these elections varied considerably from 36 to 43 percent. See: AWEPA Bulletin 31. December 2004:14.

3. A personal experience may serve as an illustration: In 1999, on a first visit to some Autarquias, in a big church in Nampula, the author met about fifty representatives from such different organizations as the Christian and Muslim communities, women, veterans, traditional authorities, peasants, teachers, and other professions. For more than two hours, they explained to a foreign expert team that it was neither political parties nor Mayors who made the real politics in the city but them, the united chapter of all local organizations. This statement was probably exaggerated but illustrates the points above, which are well documented in the literature on African politics (for instance Chabal and Daloz 1999.

4. In Transparency International's world-wide 2005 Corruption Perceptions Index, Mozambique figures in rank ninety-seven (www.transparency.org/policy_research/ surveys_indices/cpi/2005).

5. The experience of the Autarquias was well noticed by international donors, for instance the World Bank, Austria, Germany, Spain, and Switzerland. While in general, these donors have quite different philosophies, preferences, and procedures to deal with their clients, they perform rather similar programs in Mozambique's Autarquias: All of them give "hardware" support in the sense of financing infrastructure, equipment for the administration, and "software" support in the sense of training for politicians and administrators. Most Autarquias were able to attract one or even two donors, while others, like Mandlakaze and Chimoio, do without foreign aid. The advantages of attracting foreign donors can be considerable: in general, donor support is in the same proportions as a municipalities' tax revenue or transfers from central government.

6. In this and the following equations a variable name in CAPITALS means that the dichotomized variable value is 1 , while a variable name in small letters means that its value is 0. " + " stands for the logic operator "or", while "*” stands for the logical operator "and".

7. We remember that Frelimo uses participation not only as a bottom-up device to explore the preferences of the people, but also as a top-down mobilization strategy of the political elite. Direct participation, thus, has ambivalent functions and, in the Frelimo configuration, cannot be interpreted as an element of power sharing.

8. These findings contrast with the much more pessimistic comments of Braathen 2003:18 which, however, are rather general.

\section{References}

AWEPA Bulletin. 2003ff. European Parliamentarians for (southern) Africa: Mozambique political process bulletin. Amsterdam and Maputo. 
Baechler, Guenther. 1997. Federalism against ethnicity? Institutional, legal and democratic institutions to prevent violent minority conflicts. Chur and Zurich: Ruegger.

Braathen, Einar. 2003. Democratic decentralization in Mozambique? In Community and the state in Lusophone Africa, eds. Newitt Malyn, Patrick Chabal, and Norrie Macqueen, 99-126. London: King's College.

. 2004. Parties, citizens and local elections in Mozambique 2003. Working paper. Oslo: Norwegian Institute for Urban and Regional Research.

Chabal, Patrick, and Jean Pascal Daloz. 1999. Africa works. Disorder as political instrument. Oxford: The International African Institute, James Currey.

De Meur, Giselle, and Dirk Berg-Schlosser. 1996. Conditions of authoritarianism, fascism, and democracy in interwar Europe. Systematic matching and contrasting of cases for "Small N" analysis. Comparative Political Studies 29 (4): 423-68.

Davidson, Basil. 1992. The black man's burden. Africa and the curse of the nation state. New York: Random House.

Hyden, Goran. 2006. African politics in comparative perspective. New York: Cambridge University Press.

Kaelin, Walter. 1999. Decentralization - Why and how? In Decentralization and development. Bern: Swiss Agency for Development and Cooperation Publications on Development.

Linder, Wolf. 2002. Political challenges of decentralization. Washington DC: The World Bank Institute.

Linder, Wolf, and André Baechtiger. 2005. What drives democratization in Africa and Asia? European Journal of Political Research 44: 861-80.

Lijphart, Arend. 1984. Democracies. Patterns of majoritarian and consensus government in twenty-one countries. New Haven: Yale University Press.

. 1999. Patterns of democracy. Government forms and performance in thirty-six countries. New Haven and London: Yale University Press.

Litvack, Jennie, Ahman Junaid, and Richard Bird. 1998. Rethinking decentralization in developing countries. Washington DC: The World Bank.

Lutz, Georg, and Wolf Linder. 2003. Traditional structures and local governance for development and state-building. Bern and Washington DC: The World Bank Institute.

Manor, James. 1999. The political economy of democratic decentralization. Washington DC: The World Bank.

Matusse, Angelo, Marta Langa, and Adriano Nuvunga. 2003. As primeiras Autarquias em Moçambique. Maputo, Mozambique: Association of European Parliamentarians for Africa.

Merkel, Wolfgang. 2004. Systemtransformation. Eine Einführung in die Theorie und Empirie der Transformationsforschung. Opladen: Leske.

Moore, Mick. 2001. Political underdevelopment. What causes "bad governance". Public Management Review 3 (3): 385-418. (www.tandf.co.uk/journals). 
Müller, Hanspeter. 1996. Weltsystem und kulturelles Erbe. Gliederung und Dynamik der Entwicklungs-länder aus ethnologischer und soziologischer Sicht. Berlin: Reimer.

Nuvunga, Adriano. 2004. The cohabitation between the local state bodies and the local authorities in Mozambique, AWEPA, Sustainable Democracy and Human Rights. Occasional Paper Series 12: 7-27.

Oates, W. 1998. Comments on 'Fostering fiscally responsive and accountable governance: lessons from decentralization. In Evaluation and development. The institutional dimension, eds. R. Picciotto, and E. Wiesner, 97-101. New Brunswick and London: Transaction Publishers.

Oluwu, Dele, and James Wunsch. 2004. Local governance in Africa. The challenges of democratic decentralization. London: Lienne Rienner.

Putnam, Robert. 1993. Making democracy work. Civic traditions in modern Italy. Princeton: Princeton University Press.

Ragin, Charles. 1987. The comparative method. Moving beyond qualitative and quantitative strategies. Berkeley, Los Angeles and London: University of California Press.

Sager, Fritz. 2006. Policy coordination in the European metropolis. A meta-analysis. West European Politics 29(3): 433-60.

Schneider, Carsten, and Philippe Schmitter. 2004. Liberalization, transition and consolidation: Measuring the components of democratization. Democratization 11 (5): 59-90.

Sisk, Timothy. 2001. Democracy at the local level. The international IDEA handbook on participation, representation, conflict management and governance. International IDEA Handbook Series 4. Stockholm.

Sitoe, Eduardo, and Carolina Hunguana. 2007. Descentralización y construcción de una paz sostenible en Mozambique: recomponer las piezas de nuevo. In Governance, Civil Society, and Conflict, eds. Stephen Baranyi, Jennifer Salahub, and Kristiana Powell, Ottawa, Canada: The North-South Institute.

Tanzi, V. 2000. Fiscal federalism and decentralization: A review of some efficiency and macroeconomic aspects In Policies, institutions and the dark side of economics, ed. V. Tanzi, 231-63. Cheltenham: Edward Elgar.

Weimer, Bernhard. 2000. Governaçâo Local/Decentralizaçâo. In Governaçâo e democrazia em Moçambique. Prioridades para a segundo geraçao 2002-2006. Maputo, Mozambique: PNUD (Programme des Nations Unies Pour le Developpement), UNDP (United Nations Development Program).

2002. Democrazia, Governaçâo e Reforma. In Mozambique. 10 Anos de Paz, eds. Brazão Mazula et al., 55-88. Maputo, Mozambique: Universidade Eduardo Mondlane. 